\title{
Influence of the Preference Factor on the Behavior Patterns of Participation in Festival Activities
}

\author{
Shwu-Ing $\mathrm{Wu}^{1}$ \\ ${ }^{1}$ Department of Business Administration, National Chin-Yi University of Technology, Taiwan, Republic of \\ China \\ Corresponding: Shwu-Ing Wu, Department of Business Administration, National Chin-Yi University of \\ Technology, No. 57, Section 2, Zhongshan Road, Taiping, Taichung, Taiwan, R.O.C. Tel: 886-4-2392-4505.
}

Received: June 6, 2018 Accepted: July 2, 2018 Online Published: August 21, 2018

doi:10.5539/ijms.v10n3p17 URL: https://doi.org/10.5539/ijms.v10n3p17

\begin{abstract}
Festival activity marketing is one of the most popular tourism strategies around the world. Festival activities combined with marketing for interacting and communicating with the tourists, can enhance tourists' preferences and impressions on the tourism destinations and it becomes an important source in leading the development of regional economic. Festival activities held in each and every region shall be coordinated with relevant factors to integrate into distinguishing features and be implanted deeply into people's mind, and only after different marketing strategies are prepared for tourists with different preferences, can the best result of festival activities be achieved.

This study mainly discusses whether there are any difference in the pattern of associations of the tourist groups with different preference on festival activity in regards to relevant factors on festival activities, festival attractiveness, tourists' cognitive values, and behavioral intention. The result witnesses that: (1) the cognitive value of tourist groups with high preference for festival activities further promotes their behavioral intention for participating in festival activities; (2) tourist groups with medium preference for festival activities feel attracted by the favorable atmosphere of the environment, which fosters their intention to participate in festival activities. Therefore, suitable and satisfactory festival marketing strategies shall be established for different types of tourist division.
\end{abstract}

Keywords: festival activities, cognitive value, behavioral intention

\section{Introduction}

In recent years, the demand of consumers has gradually turned to the psychological level. Therefore, more and more attention has been paid to sightseeing tourism and leisure recreation. And the increase in leisure recreation demand and the change in the pattern of industrial activities have led to the attention to "festival activities and industrial tourism". The sightseeing and leisure industry has integrated sightseeing tourism, gourmet dining, product innovation, history \& culture, local distinguishing features, etc. into festival activities, and it is also expected to bring economic development to the region. Therefore, festival activities have become an important policy of all local governments in promoting the local cultural industry and local development.

Taiwan has the elements for developing festival sightseeing. Therefore, all regions in Taiwan are active in organizing festival activities, expecting to attract tourists with activities to provide opportunities for local business and expand local finances effectively (Chen, 2014). Festival activities combining with local unique history and culture not only strengthen the local image, which becomes the main attraction for the tourists, but also drive the development of the local economy (Yoon \& Uysal, 2005). Therefore, various forms of festival activities have become an important marketing method for all countries in developing tourism, and it is also the most watched and sought-after tourism trend today (Burr, 1997; Cunningham, 1995). Therefore, how to highlight the distinguishing features of festival activities to gain popularity and attract people's attention with limited resources is particularly important.

Festival activities can trigger tourists' curiosity about a region and can stimulate people's motivation and emotions on visiting. Festival commodities and environmental factors are tourists' unified impressions of a region, which can increase tourists' preference and participation intention and behavior (Wu \& Tian, 2017). For 
example: The selling of distinguishing featured commodities related to the festival in shops around the activity venues, good local transportation planning, complete natural landscape and infrastructure, thus enhancing the tourists' positive emotional reactions, and further affecting the participating behaviors and decisions (Berry \& Parasuraman, 1996); Mehrabian \& Russell, 1974). Therefore, by combining the geographical resources, cultural connotations, and traditional arts and crafts activities into unique local distinguishing features, we can attract more tourists to visit. All of these are associated influential factors that cannot be ignored.

The primary goal of festival activities planning is to attract people to participate. Therefore, the creation of attractiveness is very important. Regardless of festival distinguishing features, festival commodities, environmental atmosphere or cultural connotation, all of which are used to increase the sense of value of the tourists through actual experience. Therefore, during the tourism experience, the festival activities held in the local area must be combined with festival commodities, environmental atmosphere or cultural connotations, and be matched with the needs of tourists in order to enhance the impression and sense of value of the tourists and further strengthen the tourists' cognitive value and behavioral intention (McLuhan, 2000).

Based on the above research background and motivation, the main purpose of this study is to explore the distinguishing features of festivals, festival commodities, environmental atmosphere and cultural connotation, influence on festival attractiveness, and explore the influence of attractiveness of festival activities on tourists' cognitive value and behavioral intention; with further comparison of differences in the behavioral patterns of tourists with different preferences on festival activities. As there were previous studies on the development of festival activities, but few multivariate in-depth explorations of the above-mentioned facet, also there was few analysis and comparison on divisions of different types of tourists conducted. Therefore, this study selects festival activities as the subject of this study, and conducts relevant surveys for tourists participating in certain kind of festival activities, and divides the types of tourists into different preference groups, in order to analyze the feelings of different types of tourists on festival activities, and with suggestions from the perspective of tourists, in order to promote formulation of festival marketing strategy.

\section{Literature Review and Hypotheses}

\subsection{Influence of Distinguishing Features of Festival on Festival Attractiveness}

Festival activity is an activity category in activity marketing, which is linked with local celebrations and during the celebration period, with the support of local sponsors, forming a special and meaningful activity (Getz, 1997). Jackson (1997) interpreted from the perspective of activity content as follows: Festivals is a special event that covers products, services, ideas, information, and group characteristics. Therefore, festivals celebrations in different regions can not only attract tourist tide, but also provide the most direct and specific propaganda channels of the local culture, helps to shape regional image and improve visibility of the region (Hinch, 1996).

Gunn (1994) pointed out that for tourism, if the marketing provides propulsive force, then attractiveness provides traction force. Attractiveness promotes the tourist behavior, provides tourists with power to actuate to go, plays an important key role in catalyzing the participation of tourists, and encourages tourists' behaviors to go to the tourist spots and stay to taste, and experience in their destination (Page, 2003). If the distinguishing features of the festival can achieve goals such as activating specific regions of the city, providing opportunities that art organizations requires, integrating history and culture into the region, increasing the willingness of the people to participate in related activities, promoting continuous execution of activities, which represent that their activities are full of festival attractiveness (Frost-Kumpf, 2001).

The distinguishing features of festival activities must be acquired through individual experiences. The values of distinguishing features of the festival activities are the feelings obtained by the tourists in the individual's senses, perceptions, minds, and behaviors after interacting with the surrounding environment when involved in festival activities (Wu \& Zheng, 2014). Therefore, in addition to attentions on festival commodities, services, sense of novelty and pleasure, the tourists should also enjoy the ultimate feeling of emotion as they participate in the activities, as these would bring the tourists with pleasant mood and unforgettable memories. The more distinguishing features that the festival activities owns, the more attractive the festival would be (Pine \& Gilmore, 1998). Saleh \& Ryah (1993) also found that whether the content of the activity was of distinguishing features is the main decision factor when tourists plan their visits, which included the combination of activity content itself and the features of environmental ambiance. Therefore, the distinguishing features of festival are an important attractiveness factor that triggers tourists to visit. It includes the connotation of festival activities, distinguishing features of the activities, marketing\& spreading, and the relationship with the society and culture, all of which can motivate tourists to understand traditional culture, and better reflect the tourism value of the region (William, 1997). 
Based on the above, this paper proposes the following hypothesis:

H1: Distinguishing features of festival significantly enhance the attractiveness of festival activities.

\subsection{Influence of Festival Commodities on Festival Attractiveness}

In recent years, it has become a trend to use regional culture as a basis to design culturally creative commodities, in order to present distinguishing features in festival commodities, attract consumers' attention, and market through festival activities. Commodity fairs are a common culture in Asian countries. Tourists from countries such as Thailand, Taiwan, and Hong Kong enjoy visiting commodity fairs (Maruyama \& Trung, 2010). Commodity fair is a fixed trading venue for the concentration of commodities. Many shops or stalls are gathered in this space to sell a wide range of commodities, which are often set up around the festival activities, with a unique style specific to their own local culture and customs, and often matching with festival programs and entertainment activities (Kinnunen \& Haahti, 2015). Therefore, when there is festival activity, the surrounding commodity market is an indispensable item.

Festival commodities of distinguished features attract different groups to chase after for purchasing or collection, enable the festival activities to attract more people to participate. Rifkin (2000) pointed out that turning cultural customs and cultural activities into festival commodities and putting cultural values into service, commodities and experience, could make the whole process of consumption meaningful. Therefore, the festival commodities provide a link to combine the cultural connotation and the celebration story, while the creation and sale of the creative festival commodities can reach the crowd-gathering influence on attracting crowds, and also create the attractiveness of festival activities.

Based on the above, this paper proposes the following hypothesis:

$\mathrm{H} 2$ : Distinguishing features of festival commodities significantly enhance the attractiveness of festival activities.

\subsection{Influence of Environmental Ambiance on Festival Attractiveness}

Baker, Grewal, Parasuraman \& Voss (2002) pointed out that customers often assess whether the store meets its value needs on the energy and time cost spent on the store environment and the quality of the store, which they use as a reference for the next visit. The environmental atmosphere in this study refers to the surrounding physical environment where the festival activities take place, covering mainly the specific external space environment for tourist activities, including: Natural landscapes, leisure facilities, infrastructure, transportation convenience and overall atmosphere, all of which affect consumer emotions and behaviors (Bitner, 1992). Through the stimulating of the ambient atmosphere and the emotional factors of individual personality traits of tourists, the environmental atmosphere can trigger personal emotional reactions, such as pleasure, awakening, dominance, and other emotional states, which in turn trigger behaviors of approaching or avoiding (Mehrabian \& Russell, 1974). Therefore, the environmental atmosphere can create a good image of the region and make invisible service tangible and affect customers' expectations and satisfaction (Booms \& Bitner, 1981). Therefore, tourists regard the environmental ambiance of the venue where festivals are held as a decision factor for tourism, and consider it as an appraisal factor for assessing the attractiveness of festivals.

Beerli \& Martín (2004) also pointed out that natural and cultural features, leisure and facilities, surrounding atmosphere, safe environment and tourism resources are all elements of the physical environment, which together shape the overall environmental perception of the people and thus affect the emotions of the tourists, and further affect the attractiveness of the tourist site. While the atmosphere of the service premises, such as: music, lighting, odor, color, arrangement, etc., all increase or inhibit consumers' approach-avoidance behavior (Pine \& Gilmore, 1998). The consumers' value of experience is positively affected by interacting with the surrounding environment (Baker, (2006). Therefore, the environmental ambiance influences the perception and subjective behavior criteria of consumers (Baker et al., 2002). Therefore, a good environment positively affects the feelings of tourists and enhances festival attractiveness.

Based on the above, this paper proposes the following hypothesis:

H3: Good environmental ambiance significantly enhances the attractiveness of festival activities.

\subsection{Influence of Cultural Connotation on Festival Attractiveness}

Over time, ethnic divisions and regional changes form different groups. The same group shares the same beliefs and values, forming a regional and unique cultural connotation. Cultural connotation is the basis of tourism development, and only the tourism activities based on "cultural connotation" can attract tourists to stay for a long time and create their own brand of urban culture, like "Dajia Matsu International Tourism Culture Festival" in Taichung and "Donggang King Boat Festival" in Pingtung, both are representative examples of cultural festival 
activities. These activities have a profound cultural connotation as the main axis of the festival. Therefore, they can attract millions of tourists and performers from all over the world every year to celebrating these great festivals. This shows that cultural connotation is the basis for the development of tourism and is an important factor that attracts tourists for visiting.

Lew (1987) pointed out that the attractiveness of sightseeing spots is constituted of "landscapes", "participate", "remember" and services and facilities that satisfy tourists. Cultural factors, such as visits to historical and cultural sites, are one of the major tourism motives. Sightseeing activity without cultural connotation is just like body without soul (Kozak, 2002). Therefore, the trend of sightseeing has a trend to transforming to cultural tourism, and only cultural connotation can form a strong and powerful tourist attraction power which can increase people's motivation for participation (George, 2015).

Based on the above, this paper proposes the following hypothesis:

H4: Cultural connotation significantly enhances the attractiveness of festival activities.

\subsection{The influence of Festival Attractiveness on Tourists' Cognitive Value and Behavioral Intention}

Zeithaml (1988) defined the cognitive value of consumers as: Consumers assess the overall influence and utility of the product based on the benefits they receive and the price they pay. While Engel, Blackwell, and Miniard (2001) pointed out that cognitive value was differences between the value of the resources that were paid for and the benefits that were obtained, in which include cognitive acquisition value and cognitive transaction value. Therefore this study defines the cognitive value as the tourists' perceptions, opinions, beliefs and knowledge of festival activities, and if with positive inclination, this triggers tourists' behavioral intention.

Behavioral intension refers to the tendency of a consumer to take a specific activity or behavior with respect to a product or service (Engel et al., 2001); refers to possible repurchasing actions to trade for related products or services with recommendation willingness and transaction willingness. Zeithaml, Berry \& Parasuraman (1996) suggested that behavioral intent could be regarded as an indicator of whether a company could successfully retain customers. It is divided into five aspects: Loyalty, paying more, conversion tendencies, external reactions and internal reactions. Behavioral intention therefore refers to the tendency of tourists to participate in actions or behavioral intention for the future festival activities.

The attractiveness of tourist areas is a key reason for tourists to visit (Chi, Chua, Othman \& Karim, 2013), which is closely related to the expected cognitive interests of tourists, and influences the final decision of tourists, causing tourists' perceived value and follow-up travel behavior (Wu \& Tian, 2017). The attractiveness of tourist areas is important for attracting tourists. When people feel that the attractiveness of a certain area is higher, the cognitive value of tourists also increases, and more trips to such region occur. Therefore, the attractiveness of tourist areas enhances the cognitive value of tourists, and also increases people's behavioral intention and actual behaviors in the tourist areas (Hu \& Ritchie, 1993).

Based on the above, this paper proposes the following hypotheses:

H5: The attractiveness of festival activities significantly increases the tourists' cognition value for festival activities.

H6: The attractiveness of festival activities significantly increases the tourists' behavioral intention for attending festival activities.

\subsection{Influence of Tourists' Cognitive Value on their Behavioral Intention for Attending Festival Activities}

Since most tourists collect information about the place they plan to visit, or they are interested after being stimulated by external marketing materials, and they have some basic knowledge of the place, triggering their behavioral intention to visit such regions; and only after they truly visit such place with firsthand experience and understanding can they produce emotions towards such region or activities (Wu \& Tian, 2017).

Ajzen \& Manstead (2007) indicated that behavioral intention was influenced by three factors, including personal attitudes, subjective norms, and perceptual behavioral control. Baker \& Crompton (2000) pointed out that during festivals, the tourists' cognitive value towards celebration activities positively affects their behavioral intentions. Hawkins, Best \& Coney (2001) also suggested that cognitive values and behavioral intentions have a mutually stimulatory influence relationship.

Based on the above, this paper proposes the following hypothesis:

H7: The tourists' cognition value towards festival activities significantly increases their behavioral intention for attending festival activities. 


\subsection{Analysis of Differences among Different Types of Tourists}

As one's personal preference for something directly affects his/her behavioral pattern (Bhat\& Reddy, 2001; Caldwell \& Hibbert, 2002), such as, behavioral difference on festivals of cross-country, cross-cultural (Clair, 2013). Therefore, this study provides difference comparison on visitors of different preference for festival activities and divides them into tourists of high preference for festival activities and tourists with medium preference for festival activists. Where for group with different preference for festival activities, whether there are any differences in the intensity of festival attractiveness in regards to festival commodities, environmental atmosphere, cultural connotation, etc.? What is the difference in the path of the influence of tourists' cognitive values on their behavioral intentions? All of these need to be further explored. Therefore, this study uses festival activities as the subject, and discusses the distinguishing features of four subjects as to festivals, festival commodities, environmental atmosphere, and cultural connotation, their intensity of influence on the attractiveness of festival, tourists' cognitive value and the behavioral intentions, and by comparing the differences between groups of different preference to make a detailed in-depth analysis of their similarities and differences. Based on the above, this paper proposes the following hypothesis:

H8: Tourists with different preferences on festival activities have significant differences in the behavioral pattern of festival activities.

\section{Research Design}

\subsection{Research Framework}

Based on the above literature review, this study establishes research hypotheses and research frameworks, and with qualitative studies, questionnaire design and sample surveys and quantitative study of analysis to verify the research hypothesis and the proposed concept model. The framework of this study is shown in Figure 1.

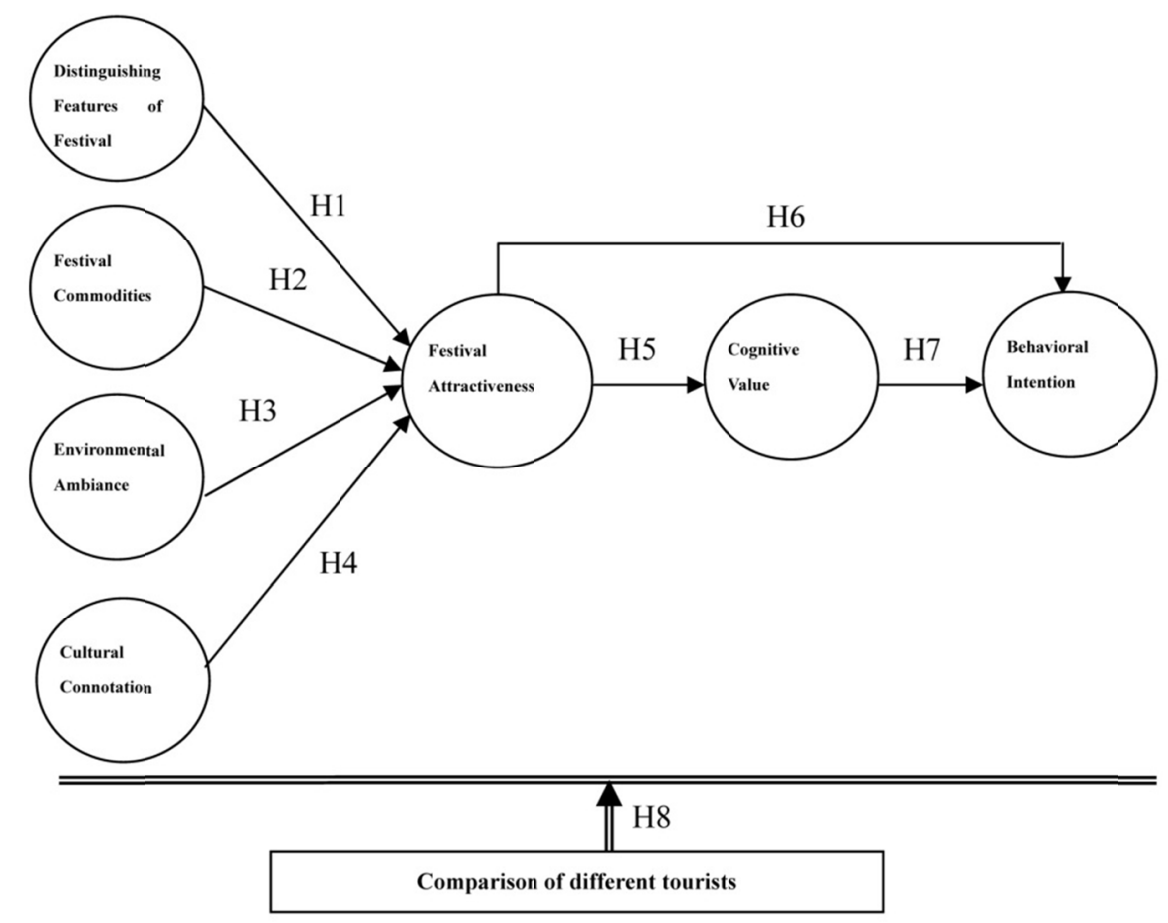

Figure 1. Research framework

\subsection{Questionnaire Design}

This study first collects relevant theories and literature as the basis for the research structure and designs a preliminary draft of the questionnaire so as to use the questionnaire survey method to collect primary data for analyzing. The questionnaire consists of 8 parts: The first part is the distinguished features of festivals with a total of 5 questions; the second part is for festival commodities with a total of 5 questions; the third part is the environment atmosphere with a total of 5 questions; the fourth part is the cultural connotation with a total of 5 questions; the fifth part is festival attractiveness with a total of 7 questions, the sixth part is cognitive value with a total of 4 questions and the seventh part is behavioral intention with a total of 4 questions. The measurement 
was based on a Likert 7-point scale, ranging from 1 (strongly disagree) to 7 (strongly agree). The eighth part is the background information of the respondents with a total of 9 questions, to be scored according to the nominal scale.

\subsection{Pretest and Pilot}

Before the release of formal questionnaires, this study conducts a two-stage questionnaire revision in order to pretest and pilot. The pretest section uses convenience sampling method to select 50 individuals who participated in festival activities for in-depth interviews, and some sentences with unclear semantics were corrected. The pilot section is based on the corrected questionnaire, and use convenience sampling method to select 80 respondents for interview and execute reliability and validity analysis. The result shows that the Cronbach $\alpha$ values of each measured facet meet the criteria of greater than 0.7 (Nunnally, 1978), and the correlation coefficient of the sub item to the total item is greater than 0.5 (Kerlinger, 1978), indicating that the reliability of each facet is good. The results of Exploratory Factor Analysis (EFA) show that the eigenvalues of all facets are greater than 1, the cumulative explanatory variation is greater than 0.5 , and the factor loading of each variable is greater than 0.5 , indicating the convergent validity of each facet (Kaiser, 1958). Therefore, this questionnaire is followed with a formal investigation.

\section{Data Analysis}

\subsection{Sample Structure}

This study takes tourists who participated in any kind of festival activities as sample objects, and provides convenience sampling investigation by delivering questionnaires by personnel. A total of 600 questionnaires were distributed. After eliminating the invalid questionnaires, there were 535 valid questionnaires with effective recovery rate of $89.17 \%$. According to a sample analysis, $43.4 \%$ were men and $56.6 \%$ were women, with most respondents aged from 35 to 44 years old, accounting for $27.1 \%$, followed by those aged 15 to 24 , accounting for $26.7 \%$. The maximum respondents living in northern area was $38.7 \%$, followed by the central area, accounted for $33.1 \%$. The respondents with education degree of universities/college accounted for $64.5 \%$, followed by high school (vocational) accounting for $24.1 \%$. The respondents working in service industries accounted for $26.2 \%$, followed by students, $20 \%$. The respondents with average monthly income between NTD 20,001 and NTD 40,000 accounted for $38.1 \%$, followed by the "NTD 20,000 or less" group accounting for $36.3 \%$.

\subsection{Reliability and Validity Analysis}

This study executes reliability and validity analysis based on 535 valid questionnaires. According to what Nunnally (1978) had proposed, the Cronbach $\alpha$ value should be greater than 0.7. Kerlinger (1978) suggested that the correlation coefficient of the total items must be greater than 0.5, all the Cronbach $\alpha$ values and correlation coefficients of the measured facets of this study are in line with these standards, so the overall reliability of the questionnaire in this study is good (as shown in Table 1). According to Kaiser (1958), the factor value of the extracted factors of factor analysis should be greater than 1, the factor loading of each variable in each factor facet should be greater than 0.5 , and the cumulative explanatory variation should be greater than 0.5 , and it can be learned that the questionnaire has good convergence validity judged on these standards (as shown in Table 1).

This questionnaire is based on domestic and foreign relevant literature and scales as the first draft of the questionnaire design, and the pilot questionnaire is formed after discussion and revision by scholars and experts. The scale is finalized through the pretest, which shows that the questionnaire has content validity. This study uses the theoretical and empirical evidences presented by experts and scholars as the basis for developing the research framework and model. Therefore, it has good validity. 
Table 1. Reliability and validity analysis of formal questionnaire

\begin{tabular}{|c|c|c|c|c|c|c|}
\hline Factor and Item & $\begin{array}{l}\text { Average } \\
\text { Value }\end{array}$ & $\begin{array}{l}\text { Item-to-total } \\
\text { correlation } \\
\text { coefficient }\end{array}$ & $\begin{array}{l}\text { Factor } \\
\text { loading }\end{array}$ & Eigenvalue & $\begin{array}{l}\text { Cumulative } \\
\text { explanatory } \\
\text { variation \% }\end{array}$ & $\begin{array}{c}\text { Cronbach } \\
\alpha\end{array}$ \\
\hline \multicolumn{7}{|l|}{ Distinguishing Features of Festival } \\
\hline The festival activity is unique. & 5.9458 & 0.765 & 0.856 & \multirow{5}{*}{3.587} & \multirow{5}{*}{71.742} & \multirow{5}{*}{0.901} \\
\hline The festival activity is rich in content. & 5.7421 & 0.797 & 0.878 & & & \\
\hline The festival activity is well known. & 5.7178 & 0.729 & 0.828 & & & \\
\hline The festival activity can enhance local features. & 5.8991 & 0.731 & 0.829 & & & \\
\hline The festival activity can highlight local features. & 6.0411 & 0.750 & 0.844 & & & \\
\hline \multicolumn{7}{|l|}{ Festival Commodities } \\
\hline The festival commodities are creative. & 5.0523 & 0.834 & 0.889 & \multirow{5}{*}{3.921} & \multirow{5}{*}{78.428} & \multirow{5}{*}{0.931} \\
\hline The festival commodities are commemorative. & 5.1458 & 0.854 & 0.913 & & & \\
\hline The festival commodities are amusing. & 4.9888 & 0.880 & 0.930 & & & \\
\hline The festival commodities are entertaining. & 4.9196 & 0.789 & 0.866 & & & \\
\hline The festival commodities are practical. & 4.5533 & 0.724 & 0.816 & & & \\
\hline \multicolumn{7}{|l|}{ Environmental Ambiance } \\
\hline $\begin{array}{l}\text { The surrounding environment of the festival is } \\
\text { good. }\end{array}$ & 5.1888 & 0.583 & 0.697 & \multirow{5}{*}{3.863} & \multirow{5}{*}{77.266} & \multirow{5}{*}{0.924} \\
\hline The festival venue is suitable. & 4.9570 & 0.882 & 0.931 & & & \\
\hline The public facilities of the festival are perfect. & 4.8355 & 0.882 & 0.932 & & & \\
\hline The festival has convenient transportation. & 4.8486 & 0.826 & 0.894 & & & \\
\hline The atmosphere of the festival is very good. & 4.8916 & 0.860 & 0.918 & & & \\
\hline \multicolumn{7}{|l|}{ Cultural Connotation } \\
\hline The festival activity is with humanistic spirit. & 5.7327 & 0.852 & 0.908 & \multirow{5}{*}{4.124} & \multirow{5}{*}{82.482} & \multirow{5}{*}{0.947} \\
\hline The festival activity is with cultural connotation. & 5.7383 & 0.894 & 0.936 & & & \\
\hline $\begin{array}{l}\text { The festival activity is with local cultural } \\
\text { features. }\end{array}$ & 5.7364 & 0.892 & 0.934 & & & \\
\hline $\begin{array}{l}\text { The festival activity is a grand local sightseeing } \\
\text { event. }\end{array}$ & 5.8318 & 0.839 & 0.898 & & & \\
\hline $\begin{array}{l}\text { The festival activity includes cultural } \\
\text { monuments. }\end{array}$ & 5.6187 & 0.792 & 0.864 & & & \\
\hline \multicolumn{7}{|l|}{ Festival Attractiveness } \\
\hline $\begin{array}{l}\text { Participating in this festival activity can increase } \\
\text { interaction with others. }\end{array}$ & 5.5196 & 0.784 & 0.844 & \multirow{7}{*}{5.266} & \multirow{7}{*}{75.223} & \multirow{7}{*}{0.945} \\
\hline $\begin{array}{l}\text { Participating in this festival activity can promote } \\
\text { feelings between the peoples. }\end{array}$ & 5.5720 & 0.796 & 0.853 & & & \\
\hline $\begin{array}{l}\text { Participating in the festival activity is } \\
\text { memorable. }\end{array}$ & 5.4467 & 0.814 & 0.867 & & & \\
\hline The festival activity is creative. & 5.3234 & 0.820 & 0.871 & & & \\
\hline The festival is very attractive. & 5.3925 & 0.881 & 0.917 & & & \\
\hline The festival activity is graceful in style. & 5.0916 & 0.815 & 0.864 & & & \\
\hline The festival activity is with sound effect. & 5.2879 & 0.801 & 0.853 & & & \\
\hline \multicolumn{7}{|l|}{ Cognitive Value } \\
\hline The festival activity is of positive value. & 5.7215 & 0.750 & 0.858 & \multirow{4}{*}{2.987} & \multirow{4}{*}{74.669} & \multirow{4}{*}{0.887} \\
\hline Festival activities can satisfy the leisure needs. & 5.5981 & 0.722 & 0.839 & & & \\
\hline $\begin{array}{l}\text { Festival activities can enhance sightseeing } \\
\text { benefits. }\end{array}$ & 5.9907 & 0.778 & 0.888 & & & \\
\hline $\begin{array}{l}\text { Festival activities can promote local } \\
\text { development. }\end{array}$ & 6.1047 & 0.753 & 0.870 & & & \\
\hline Behavioral Intention & & & & & & \\
\hline I like to participate in festival activities. & 5.2542 & 0.769 & 0.872 & & & \\
\hline $\begin{array}{l}\text { Participating in festival activities is an important } \\
\text { issue. }\end{array}$ & 4.6935 & 0.768 & 0.872 & 3.047 & 76.175 & 0.896 \\
\hline I like the atmosphere of festival activities. & 5.5065 & 0.762 & 0.869 & & & \\
\hline I would recommend the festivals to others. & 5.3271 & 0.775 & 0.878 & & & \\
\hline
\end{tabular}




\subsection{Confirmatory Factor Analysis}

In order to verify the effectiveness of the facets, this study conduct a confirmatory factor analysis (CFA) using the AMOS software's measurement model on distinguishing features of festivals, festival commodities, environmental atmosphere, cultural connotation, festival attractiveness, cognitive value, and behavioral intention. According to the rigorous principle, the suitability index of the measurement model must meet the followings, that the $\chi^{2} / \mathrm{df}$ ratio shall be not more than 3 (Carmines \& McIver, 1981), RMSEA shall be less than 0.05, and GFI, AGFI, NFI, RFI, and CFI shall be greater than Principles of 0.9 (Bagozzi \& Yi, 1988; Joreskog \& Sorbom, 1989). The result shows that the fitness index of the measurement mode is moderate with the $\chi^{2} / \mathrm{df}$ value of 1.816 , the RMSEA value of 0.039 , the GFI value of 0.841 , the AGFI value of 0.800 , the NFI value of 0.901 , the RFI value is 0.882 , and the CFI value of 0.952 . All of the above results are in line with or close to the ideal standard, indicating that this measurement model is acceptable. Therefore, the measurement index has construct validity and measurement efficiency.

\subsection{Competing Model}

This study groups tourists according to their preference for festival activities, with 290 people with high preference and 245 people with medium preference. Then the competition mode analysis is conducted through AMOS software to understand the causality between groups and the differences between groups. The result shows that the $\chi^{2} / \mathrm{df}$ value is 1.807 , the RMSEA value is 0.039 , the GFI value is 0.840 , the AGFI value is 0.800 , the NFI value is 0.900 , the RFI value is 0.882 , and the CFI value is 0.952 . This result is in line with the good model principle. Therefore the competition mode of this study is of the best suitability, showing that this mode is acceptable.

\subsection{The Path Comparison of the Two Groups' Pattern}

The analysis of the paths between the various facets shows that the relationship between the two groups is somewhat different as follows:

Tourists with a high or medium preference for festival activities have significant positive influence on festival attractiveness in respect of distinguishing features of festival, festival commodities, environmental atmosphere and cultural connotations, the result of which is supportive for $\mathrm{H} 1, \mathrm{H} 2, \mathrm{H} 3$, and $\mathrm{H} 4$; Tourists with a high or medium preference for festival activities having significant positive influence on the cognitive value, the result of which is supportive for H5; Tourists with medium preference for festival activities have significant positive influence on behavior intentions. While for those with a high preference for festival activities have no significant positive influence, the result of which is partially supportive for H6. Tourists with a high or medium preference for festival activities have significant positive influence on the relationship between cognitive value and behavioral intention, the result of which supports H7. The model analysis results are shown in Table 2.

This study further compares the intensity of the influence on the path of tourists with different preferences (as shown in Table 2), and the results are as follows:

(1) Through analyzing the influence of "environmental ambiance" on "festival attractiveness", we can see that tourists with a high or medium preference for festival activities have significant differences in the path of this relationship. According to the result of the $t$ test, tourists with a medium preference for festival activities have a stronger influence on the path of this relationship.

(2) According to the influence of "festival attractiveness" on "behavioral intention", tourists with a high or medium preference for festival activities have significant differences in the path of this relationship. According to the result of the $t$ test, we can see that tourists with a medium preference for festival activities have a stronger influence on the path of this relationship.

(3) Through analyzing the influence of "cognitive value" on "behavioral intention", we can see that tourists with a high or medium preference for festival activities have significant differences in the path of this relationship. According to the result of the $t$ test, tourists with a high preference for festival activities have a stronger influence on the path of this relationship.

Under the comparison of different types of tourists' relationship models, there is significant difference in different preferences on the path intensity of "environmental atmosphere" on "festival attractiveness", and "festival attractiveness" on "behavioral intention", and "cognitive value" on "behavioral intention". Thus H8 is partially supported. 
Table 2. Comparison of different types of tourists' relationship models

\begin{tabular}{|c|c|c|c|}
\hline \multirow[b]{2}{*}{ Paths } & \multicolumn{2}{|c|}{ Standardized parameter estimates } & \multirow[b]{2}{*}{ T-test } \\
\hline & High preference group & $\begin{array}{l}\text { Medium preference } \\
\text { group }\end{array}$ & \\
\hline $\begin{array}{l}\text { H1: Distinguishing Features of Festival } \\
\rightarrow \text { Festival Attractiveness }\end{array}$ & $0.246^{* * *}$ & $0.136^{*}$ & -1.199 \\
\hline $\begin{array}{l}\mathrm{H} 2: \text { Festival Commodities } \\
\rightarrow \text { Festival Attractiveness }\end{array}$ & $0.235^{* * *}$ & $0.251^{* * *}$ & 1.274 \\
\hline $\begin{array}{l}\text { H3: Environmental Ambiance } \\
\rightarrow \text { Festival Attractiveness }\end{array}$ & $0.111^{* *}$ & $0.251 * * *$ & $2.979 *$ \\
\hline $\begin{array}{l}\text { H4: Cultural Connotation } \\
\rightarrow \text { Festival Attractiveness }\end{array}$ & $0.428 * * *$ & $0.369 * * *$ & -0.904 \\
\hline $\begin{array}{l}\mathrm{H} 5: \text { Festival Attractiveness } \\
\rightarrow \text { Cognitive Value }\end{array}$ & $0.933 * * *$ & $0.941 * * *$ & -0.158 \\
\hline $\begin{array}{l}\text { H6: Festival Attractiveness } \\
\rightarrow \text { Behavioral Intention }\end{array}$ & 0.056 & $0.378 * * *$ & $2.429 *$ \\
\hline $\begin{array}{l}\text { H7: Cognitive Value } \\
\rightarrow \text { Behavioral Intention }\end{array}$ & $0.791 * * *$ & $0.465 * * *$ & $-2.015^{*}$ \\
\hline
\end{tabular}

\section{Conclusion and Suggestions}

\subsection{Conclusion}

From the tourists' point of view of , this study uses festival activities as the subject of research; through empirical research, it deeply explores the influence of distinguishing features of festivals, festival commodities, environmental atmosphere and cultural connotations on tourists' festival attractiveness, cognitive values and behavioral intention, and establish associated models and efficient metrics, which are of academic and practical value. Through comparative analysis of competitive models, it is found that:

(1) Distinguishing features of festivals, festival commodities, environmental atmosphere, and cultural connotations influence the festival attractiveness:

Tourist groups, regardless with a high or medium preference for festival activities, all have significant positive influence on the festival attractiveness in regards to the distinguishing features of festivals, festival commodities, environmental atmosphere and cultural connotation. This result is consistent with the concept proposed by Pine \& Gilmore (1998) and Rifkin (2000) Baker (2006) and George et al. (2015). It indicates that visitors feel the improvement of attractiveness of festival activities in regards to activities contents, performances, merchandise, physical infrastructure, leisure facilities and cultural connotations presented by the festival. The attractiveness of festival activities increases tourists' interest and impression, and can also induce tourists to go to the tourist spots and stay to have a taste and experience. Therefore, distinguishing features of festivals, festival commodities, environmental atmosphere and cultural connotation provide positive uplifting influence on festival attractiveness.

\section{(2) The Influence of Festival Attractiveness on Cognitive Value and Behavioral Intention}

The tourist groups with a high or medium preference for festival activities have a significant positive influence on the path of attractiveness to the cognitive value. This result is consistent with $\mathrm{Wu} \&$ Tian et al. (2017). It indicates that the tourists with higher attractiveness on the festival activities increase their opinions and positive feeling towards festival activities with positive comments. Therefore, the positive attractiveness of festivals has a significant positive relationship with the cognitive value.

The tourist group with a medium preference for festival activities has a significant positive influence on the behavioral intentions at the festival attractiveness. This result is consistent with Hu \& Ritchie et al. (1993). It indicates that the medium preference group participating in festival activities is more inclined to recommend the destination to others, generating positive word-of-mouth and behavior of desiring to revisit again, so the festival attractiveness positively affects the intention of the tourists in the medium preference group. Therefore, festival attractiveness is the main drive for the medium preference group to join in the activities.

The tourist group with high preference for festival activities has no significant influence on behavioral intention for festival attractiveness. This result is inconsistent with the hypothesis of this study. As by comparing with the tourist group with a medium preference for festival activities, the tourist group with a high preference for festival 
activities is with higher sensitivity, indicating that high-preference people have higher expectations for festival activities, but when they are not satisfied with the festival activities, the sense of loss is greater. Therefore, though the tourists with a high preference for festival activities feel that the festival activities are attractive, this does not result in positive behavioral intentions. It could produce a commitment conversion, and this result is noteworthiness.

(3) The Influence of Tourists' Cognitive Value on Behavioral Intention:

The tourist group with a high or medium preference for festival activities has a significant positive influence on perceived value and behavioral intentions. This result is consistent with Baker \& Crompton et al. (2000). It indicates that the distinguishing features and services provided by the festival activities, and evaluations received from the tourists influence the behavioral intentions of tourists. In particular, when the tourists' harvest and evaluation is more valuable, the tourists feel more satisfaction on festival activities, arise more reliability on such festival activities, which can encourage tourists to recommend the festival activities to relatives and friends and willing to revisit again, especially those with a high preference for festival activities.

(4) A comparison of the patterns of relationships among tourists based on different levels of preference shows:

- On the path of environmental atmosphere on festival attractiveness, the tourists with a medium preference for festival activities pay more attention to the atmosphere of the environment, including: convenient transportation, infrastructure, environmental layout and atmosphere of activities, etc., indicating that the festival activities with more complete surrounding environment planned, it has more attractiveness to the tourists with a medium preference for festival activities.

- In the path of festival attractiveness on the behavioral intention, the tourists with a medium preference for festival activities are more likely to be affected by the overall attractiveness of the festival activities and have the desire to revisit or recommend to others.

- In the path of cognitive value on behavioral intention, the tourists with a high preference for festival activities can increase their willingness to participate and with word-of-mouth activities to recommend to others after recognizing the value of festival activities.

\subsection{Managerial Implications}

Based on the empirical analysis, this study explores the degree of tourists' feelings on festival activities, and discusses the distinguishing features of festivals, festival commodities, environmental atmosphere, and cultural connotations, as well as their influence and associations with festival attractiveness, cognitive value and behavioral intentions of the tourist. The result of this study can provide important reference information for planning festival activities in various regions. Therefore, the following suggestions are proposed:

(1) The biggest charm of festival activities is the "cultural connotation"

The influence of cultural connotation is the strongest among the four variables, which means that no matter it is high or medium preference activists, the unique culture, historical values, cultural assets of the festival activities and the historical artifacts, humanities, landscapes, allusions, custom habits of the area and etc., those are important factors that attract tourists. If there is no support of rich local cultural features to touch the tourist, the destination would be difficult to maintain its popularity within the tourists. Therefore, it is a key factor in the success of the festival to make good use of local cultural resources, and protect local cultural heritage, and establish a unique local style of tourism, and further enhance the willingness of visitors to experience.

(2) Festival attractiveness is the most crucial factor to enhance the cognitive value of tourists.

"Attractiveness effect" is an important part of tourism and leisure activities that acts as a motivational catalyst for tourists. The stronger the attraction effect is, the stronger the motivation for participation would be, and it is thus clear that the attractiveness effect is important for the customer attracting effect of festival activities. Participation motivation of the masses is affected by the distinguished features of the activity itself. It should start with improving the essence of various activities such as content design and program quality to increase the attractiveness of the activity, and maximize the effectiveness of the activity to induce the people's motivation to participate. Therefore, proper planning of the activities marketing and design to enhance the attractiveness of the activity is important for promoting festivals in various regions.

Therefore, festival attractiveness is an important factor for successful management of local brands, and it is an important means for publicizing various marketing activities. Each region makes a series of introductions and explanations for the culture of festival activities, and by combining the promotion of local specialties to obtain tourists' favor. Take the "Tachia Matsu International Tourism and Culture Festival" as an example, you can 
perform a series of DIY experience activities to understand Matsu's storytelling and local specialties, taro crisps or shortbread. Therefore, good activity content design attracts tourists. The main factor is also the most effective marketing method to promote festival activities.

(3) Make good use of word-of-mouth marketing to create a tourist commitment

The ultimate goal of festivals is to create tourists' revisit promises. To create a promise, we must create word-of-mouth from festivals, communicate with the media, and tourists must spread word to word and propaganda local distinguished features. Word-of-mouth marketing is popular for a long time with certain advantage of the marketing strategy. According to market statistics, it is found that with the convenience of the network popularization of mobile networks, nearly $90 \%$ of consumers search online for evaluation or collect data before making any purchase and consumption. The trend of word-of-mouth marketing has not only affected the shopping-oriented consumption, but also has deeper influence on tourism and sightseeing.

Because the positive word-of-mouth reputation of tourists is more effective than traditional enterprise-led marketing strategies, and can provide reference sources for potential tourists' experience, thus reducing risks and uncertainties, not only retaining existing customers, but also enhancing the maintenance among the tourists. Maintaining the follow-up word-of-mouth activities to promote tourists' desire to revisit and recommend to others, thereby bringing more potential customers and more business opportunities.

\subsection{Research Limitations and Suggestions for Future Research}

The conceptual framework and empirical result established by this study can provide new perspectives as a reference for subsequent research. However, there are still some issues that need to be improved:

(1) The matrix of this study is the tourists who have participated in any festival marketing activities. Although some conclusions have been obtained from the research result, while due to the different content of festival activities, the research result may not be universally used for all festival activities. Another reason is the local distinguished features and cultural atmosphere, different marketing strategies and different levels of tourists' awareness of the region may lead to discrepancies in the research result. It is suggested that follow-up studies be conducted to discuss the different types of festivals held in different regions, and a comparative analysis be conducted to better understand the differences in tourists' feelings for festival activities of different natures, in order to plan for different groups of activities, so that more practical value can be provided.

(2) This study compares the differences of relationship model of tourists with different preferences in regards to the distinguished features of festival activities, festival commodities, environmental atmosphere, cultural connotations, festival attractiveness, cognitive values and behavioral intentions. It is recommended that follow-up studies should use other variables as the septum variable to explore the differences in the behavior of different types of tourists in tourism and leisure activities, enabling the exploration of deeper analysis.

\section{Acknowledgement}

This research was made possible through the support of the Ministry of Science and Technology of Republic of China, Taiwan, under project (MOST 106-2410-H-167-011).

\section{Reference}

Ajzen, I., \& Manstead, A. S. R. (2007). Changing health-related behaviors: An approach based on the theory of planned behavior. In K. van den Bos, M. Hewstone, J. de Wit, H. Schut, \& M. Stroebe (Eds.), The Scope of Social Psychology: Theory and Applications (pp. 43-63).

Bagozzi, R. P., \& Yi, Y. (1988). On the evaluation of structure equations models. Academic of Marketing Science, 16(1), 76-94.

Baker, D. A., \& Crompton, J. L. (2000). Quality, satisfaction and behavioral intentions. Annals of Tourism Research, 27(3), 785-804. https://dx.doi.org/10.1016/S0160-7383(99)00108-5

Baker, J., Grewal, D., Parasuraman, A., \& Voss, G. B. (2002). The influence of multiple store environment cues on perceived merchandise value and patronage intentions. Journal of Marketing, 66(2), 120-141. https://dx.doi.org/10.1509/jmkg.66.2.120.18470

Baker, S. M. (2006). Consumer normalcy: Understanding the value of shopping through narratives of consumers with visual impairments. Journal of Retailing, 82(1), 37-50. https://dx.doi.org/10.1016/j.jretai.2005.11.003

Beerli, A., \& Martín, J. D. (2004). Factors influencing destination image. Annals of Tourism Research, 31(3), 657-681. https://dx.doi.org/10.1016/j.annals.2004.01.010

Berry, Z. L. L., \& Parasuraman, A. (1996). The behavioral consequences of service quality. Journal of Marketing, 
60(2), 31-46. https://dx.doi.org/10.2307/1251929

Bhat, S., \& Reddy, S. (2001). The impact of parent brand attribute associations and affect on brand extension evaluation. Journal of Business Research, 53(3), 111-122. https://dx.doi.org/10.1016/S0148-2963(99)00115-0

Bitner, M. J. (1992). Servicescapes: Impact of physical surroundings on customers and employees. Journal of Marketing, 56(2), 57-71. https://dx.doi.org/10.2307/1252042

Booms, B. H., \& Bitner, M. J. (1981). Marketing strategies and organizational Structures for Service Firms. In J. H. Donnelly \& W. R. George (Eds.), Marketing of Services (pp. 53-60). Chicage: American Marketing Association.

Burr, S. T. (1997). Love the neighbor and prosper community festivals and events. Parks \& Recreation, 32(9), 106-118.

Caldwell, C., \& Hibbert, S. A. (2002). The influence of music tempo and musical preference on restaurant patron's behavior. Psychology \& Marketing, 19(11), 895-917. https://dx.doi.org/10.1002/mar.10043

Carmines, E. G., \& Maclver, J. P. (1981). Analyzing Models with Unobserved Variables. In G. W. Bohrnstedt \& E. F. Borgatta (Eds.), Social Measurement: Current Issues (pp. 65-115). CA: Sage Publications.

Chen, C. A. (2014). Suitable festival activities for Taiwan's tourism and nation branding with the application of the PR AHP program. Asia Pacific Journal of Tourism Research, 19(12), 1381-1398.

Chi, C. G.-Q., Chua, B. L., Othman, M., \& Karim, S. A. (2013). Investigating the structural relationships between food image, food satisfaction, culinary quality, and behavioral intentions: The case of Malaysia. International Journal of Hospitality \& Tourism Administration, 14(2), 99-120. https://dx.doi.org/10.1080/15256480.2013.782215

Clair, VA W. S. (2013). Cross-cultural understandings of festival food-related activities for older women in Chiang Mai, Thailand, Eastern Kentucky, USA and Auckland, New Zealand. Journal of Cross-Cultural Gerontology, 28(2), 103-119.

Cunningham, H. (1995). Event marketing: State of the industry and agenda. Festival Management and Event Tourism, 2(3), 123-127. https://dx.doi.org/ 10.3727/106527095792315521

Engel, J. F., Blackwell, R. D., \& Miniard, P. W. (2001). Consumer Behavior (8th ed.). Fort Worth: Dryden Press.

Frost-Kumpf, H. A. (2001). Cultural Districts: Arts Management and Urban Development. Unpublished paper.

George, J. (2015). Examining the cultural value of festivals: Considerations of creative destruction and creative enhancement within the rural environment. International Journal of Event and Festival Management, 6(2), 122-134. https://dx.doi.org/10.1108/IJEFM-01-2015-0002

Getz, D. (1997). Event management \& event tourism. N.Y.: Cognizant Communication Corp.

Gunn, C. A. (1994). Tourism Planning: Basics, Concepts, Cases (3rd ed.). Washington, DC: Taylor and Francis.

Hawkins, D. I., Best, R. J., \& Coney, K. A. (2001). Consumer Behavior, Building Marketing Strategy. NY: McGraw-Hill.

Hinch, T. D. (1996). Urban Tourism: perspectives on Sustainability. Sustainable Tourism, 4(2), 95-110. https://dx.doi.org/10.1080/09669589608667261

Hu, Y., \& Ritchie, J. R. B. (1993). Measuring destination attractiveness: A Contextual Approach. Journal of Travel Research, 32(2), 25-34. https://dx.doi.org/10.1177/004728759303200204

Jackson, R. (1997). Marketing special event fit in the 21th century. Champaign, IL: Sagamore Pub.

Joreskog, K. G., \& Sorbom, D. (1989). LISREL 7 user's reference guide. Chicago: Scientific Software.

Kaiser, H. F. (1958). The Varimax criterion for analysis rotation in factor analysis. Psychometrika, 23(3), 187-200. https://dx.doi.org/10.1007/BF02289233

Kerlinger, F. N. (1978). Foundation of Behavioral Research. NY: McGraw-Hill.

Kinnunen, M., \& Haahti, A. (2015). Visitor discourses on experiences: reasons for festival success and failure. International Journal of Event and Festival Management, 6(3), 251-268. https://dx.doi.org/10.1108/IJEFM-01-2015-0003

Kozak, M. (2002). Comparative analysis of tourist motivations by nationality and destinations. Tourism 
Management, 23(3), 221-232. https://dx.doi.org/10.1016/S0261-5177(01)00090-5

Lew, A. (1987). A framework of tourist attraction research. Annals of Tourism Research, 14(4), 533-575. https://dx.doi.org/10.1016/0160-7383(87)90071-5

Maruyama, M., \& Trung, L. V. (2010). The nature of informal food bazaars: Empirical results for Urban Hanoi, Vietnam. Journal of Retailing and Consumer Services, 17(1), 1-9. https://dx.doi.org/10.1016/j.jretconser.2009.08.006

Mcluhan, R. (2000). Go live with a big brand experience. Marketing, 26(4), 45-46.

Mehrabian, A., \& Russell, J. A. (1974). Approach to environmental psychology. Cambridge: The MIT Press.

Nunnally, J. C. (1978). Psychometric Theory. NY: Mcgraw-Hill.

Page, S. J. (2003). Tourism Management: Managing for Change. Oxford: Buterworth- Heinemann.

Pine, B. J., \& Gilmore, J. H. (1998). Welcome to the experience economy. Harvard Business Review, 76(4), 97-105.

Rifkin, J. (2000). The Age of Access. New York: J. P. Tarcher.

Saleh, F., \& Ryah, C. (1993). Jazz and knitwear: Factors that attracts to festivals. Tourism Management, 14(4), 289-297. https://dx.doi.org/10.1016/0261-5177(93)90063-Q

William, F. T. (1997). Global Tourism: The next decade. London: Butterworth-Heinemann.

Wu, S. I., \& Tian, M. L. (2017). Impact of consumers'preference for cultural and creative parks on the attitude behavior model. International Journal of Business and Management, 12(8), 201-218. https://dx.doi.org/10.5539/ijbm.v12n8p201

Wu, S. I., \& Zheng, Y. H. (2014). The Influence of tourism image and activities appeal on tourist loyalty: A study of Tainan City in Taiwan. Journal of Management and Strategy, 5(4), 121-135. https://dx.doi.org/10.5430/jms.v5n4p121

Yoon, Y., \& Uysal, M. (2005). An examination of the effects of motivation and satisfaction on destination loyalty: A structural model. Tourism Management, 26(1), 45-56. https://dx.doi.org/10.1016/j.tourman.2003.08.016

Zeithaml, V. A. (1988). Consumer perceptions of price, quality, and value: A Means-End model and synthesis of evidence. Journal of Marketing, 52(3), 2-22. https://dx.doi.org/ 10.2307/1251446

Zeithaml, V. A., Berry, L. L., \& Parasuraman, A. (1996). The behavioral consequences of service quality. Journal of Marketing, 60(2), 31-46. https://dx.doi.org/10.2307/1251929

\section{Copyrights}

Copyright for this article is retained by the author, with first publication rights granted to the journal.

This is an open-access article distributed under the terms and conditions of the Creative Commons Attribution license (http://creativecommons.org/licenses/by/4.0/). 